\title{
Water resource monitoring systems and the role of satellite observations
}

\author{
A. I. J. M. van Dijk and L. J. Renzullo \\ Water Information R \& D Alliance/CSIRO Water for a Healthy Country, G.P.O. Box 1666, Canberra, ACT 2601, Australia \\ Received: 23 July 2010 - Published in Hydrol. Earth Syst. Sci. Discuss.: 26 August 2010 \\ Revised: 29 November 2010 - Accepted: 14 December 2010 - Published: 4 January 2011
}

\begin{abstract}
Spatial water resource monitoring systems (SWRMS) can provide valuable information in support of water management, but current operational systems are few and provide only a subset of the information required. Necessary innovations include the explicit description of water redistribution and water use from river and groundwater systems, achieving greater spatial detail (particularly in key features such as irrigated areas and wetlands), and improving accuracy as assessed against hydrometric observations, as well as assimilating those observations. The Australian water resources assessment (AWRA) system aims to achieve this by coupling landscape models with models describing surface water and groundwater dynamics and water use. A review of operational and research applications demonstrates that satellite observations can improve accuracy and spatial detail in hydrological model estimation. All operational systems use dynamic forcing, land cover classifications and a priori parameterisation of vegetation dynamics that are partially or wholly derived from remote sensing. Satellite observations are used to varying degrees in model evaluation and data assimilation. The utility of satellite observations through data assimilation can vary as a function of dominant hydrological processes. Opportunities for improvement are identified, including the development of more accurate and higher spatial and temporal resolution precipitation products, and the use of a greater range of remote sensing products in a priori model parameter estimation, model evaluation and data assimilation. Operational challenges include the continuity of research satellite missions and data services, and the need to find computationally-efficient data assimilation techniques. The successful use of observations critically de-
\end{abstract}

Correspondence to: A. I. J. M. van Dijk (albert.vandijk@csiro.au) pends on the availability of detailed information on observational error and understanding of the relationship between remotely-sensed and model variables, as affected by conceptual discrepancies and spatial and temporal scaling.

\section{Introduction}

\subsection{Background}

The first spatially-distributed water resources model was conceived in the 1960s (Freeze and Harlan, 1969; Crawford and Linsley, 1966). Satellite observations were first operationally assimilated into numerical weather prediction (NWP) models in the early 1970s (Tracton and McPherson, 1977). The first operational uses of satellite observations in water resources were developed in the early 1980s (Ramamoorthi, 1983). Almost 30 years later, few satellite data are used in only a handful of operational surface water resources monitoring systems (SWRMS, reviewed further on) ${ }^{1}$. There appears to be little evidence that the information they provide has found wide uptake in water management.

This seems curious when considering the ever increasing pressure on water resources in many countries and the utility of water resource information in water management. Some benefits of SWRMS include: (1) improved spatial understanding of the water cycle and its sensitivity to climate variation, natural disturbances and human interventions; (2) generation of retrospective water resources

\footnotetext{
${ }^{1}$ We define "operational" here as producing information on a regular basis, and "spatial water resources monitoring systems" (SWRMS) as software that integrates observations into models to produce spatial estimates of current (and past) water resources distribution.
} 
accounts for policy planning and evaluation and compliance monitoring (Molden, 1997); (3) near-real time monitoring of soil, river and groundwater availability to support drought response policies and actions (Henricksen and Durkin, 1986); (4) initialisation of flood warning and water resource forecast models; and (5) data to evaluate hydrological models used for "what-if" scenario assessments.

There are indications that the development of operational SWRMS is currently progressing rapidly however, particularly now that some of the main technological obstacles have been overcome. Internet communication and telemetry have become fast and inexpensive. Reliable and accessible near-real time satellite data services have become available (though much data is still collected by research missions and therefore arguably not truly operationally reliable). Robust yet flexible information and communications technology (ICT) solutions have been developed to support the development of operational systems (Kumar et al., 2008; Werner and Whitfield, 2007). The onus, therefore, is on the hydrological community to develop modelling systems that integrate satellite and on-ground observation systems as necessary to produce water resources information that is of use to decision makers.

\subsection{Australian context}

Recent experiences in Australia provide an example where demand for water resources information has led to the development of a SWRMS. Large swathes of Australia have been experiencing extraordinary drought conditions since around 2001 prompting federal and state governments to reform water information management and dissemination. New water laws in 2007 delegated a legislative mandate and resources to the Bureau of Meteorology (BoM) to develop a range of upto-date water information services and the statutory power to request water observations from all relevant sources. Services will include an annual national water account, scheduled water resources assessments that interpret current and future water availability, and forecasts of water availability for days to decades (http://www.bom.gov.au/water/). To achieve this, BoM and the Commonwealth Scientific and Industrial Research Organisation (CSIRO) in 2008 initiated development of an underpinning SWRMS. The Australian water resources assessment (AWRA, http://connect.csiro.au/ water/) system currently exists as experimental operational systems in CSIRO and in BoM; that is, information is generated routinely and automatically but is not yet provided as a data service.

\subsection{Objective}

The aim of this paper is to assess the current state of progress, opportunities and challenges to achieve greater use of satellite observations in SWRMS. This is pursued by considering the following questions:
- What operational SWRMS currently exist?

- How do these systems use satellite observations?

- What research applications have been published that may be implemented operationally?

These questions will be considered through the prism of the water information requirements that led to the development of AWRA. A short description of the system is therefore provided.

\section{Spatial water resource monitoring systems}

\subsection{Spatial hydrological models}

Over the years, a wide range of spatial hydrological models has been developed. Several reviews of these models have been published (e.g. Kampf and Burges, 2007, and references therein). Typical applications of these models are either at the catchment or groundwater systems scale. The first dynamic hydrological model that was feasibly applicable over large areas (e.g. a continent) as well as demonstrated utility for water resources applications was the variable infiltration capacity (VIC) model, developed in the early nineties (Wood et al., 1992; Liang et al., 1994). VIC was developed with the intention to be included in global climate models (GCMs) but was also evaluated against streamflow with satisfactory results. Since then, the land surface models (LSMs) in most GCMs have received at least some attention to the representation of hydrological processes in part due to their participation in the Project for Intercomparison of Land-Surface Parameterization Schemes (PILPS; Henderson-Sellers et al., 1995, 1993) and similar initiatives. Due to their lineage, LSMs typically evolve at sub-daily time steps and have a domain and resolution commensurate with the GCM. LSMs are not primarily intended to provide water resources information and are not used widely in water management. When compared to more conventional catchment models, LSMs show poorer performance in reproducing streamflow observations and other water resources related variables (Oki et al., 1999; Nijssen et al., 2001; Wood et al., 1998; Lohmann et al., 2004). Reasons include the more elaborate parameter calibration techniques used in catchment models, and the combination of coarse resolution (of precipitation forcing in particular) and strong non-linearity in runoff generating processes. LSMs also vary in the degree to which hydrological processes important to water resources management (such as groundwater dynamics, streamflow generation and water use) are represented.

The first uses of dynamic continental to global hydrological modelling for large scale water resources assessment were published between 1998 and 2000, including the landmark study of Vörösmarty et al. (2000). Since then, several more distributed water resource models have been developed 
to help understand the characteristics and sensitivities of water resource systems. A distinguishing feature of these models is that they consider water resource generation and use. Initial studies manipulated tabulated data on aggregate water use, but in recent years models have been developed that include a dynamic description of in-river processes (the management and dynamics of reservoirs and other water bodies, extractions, irrigation water use) yet can still be applied for large areas or even globally (Döll et al., 2003).

\subsection{Operational monitoring systems}

Arguably, the only SWRMS specifically designed for use by water resource managers is the Netherlands Hydrological modelling Instrument (NHI) that was made operational very recently (Berendrecht et al., 2009; Weerts et al., 2009). It provides daily water resources estimates and forecasts across the Netherlands $\left(41526 \mathrm{~km}^{2}\right)$ at $250-\mathrm{m}$ resolution to support surface water allocation decisions during drought. The system integrates a grid-based vertical soil water model with surface and groundwater models that are coupled online with a regional surface water model and water distribution model to provide estimates of variables such as surface water and groundwater levels and root zone soil moisture.

In addition, a handful of systems exist that provide synoptic information about landscape hydrological variables. Some of these are described briefly below. While incomplete from a water resources perspective, they do provide information that can be relevant to water management, such as soil moisture status and streamflow in unregulated systems.

A Land Data Assimilation System (LDAS) technology was developed in the US to combine data from multiple sources within models to produce gridded maps of land surface states and fluxes. Implementations include the North America LDAS (NLDAS, http://www.emc.ncep.noaa.gov/ $\mathrm{mmb} / \mathrm{nldas} /$ and http://ldas.gsfc.nasa.gov/nldas/) (Mitchell et al., 2004) and the Global LDAS (GLDAS; http://ldas.gsfc. nasa.gov/gldas/) (Rodell et al., 2004). Both rely on the Land Information System (Kumar et al., 2008), a software infrastructure that drives several spatial models, including Noah, Mosaic, VIC, the Community Land Model, and the Sacramento model (for details and comparison see Mitchell et al., 2004; Rodell et al., 2004). Retrospective and updated NLDAS model output is available with five days latency, and soil moisture percentile and anomaly maps are provided through the experimental NLDAS Drought Monitor website (http: //www.emc.ncep.noaa.gov/mmb/nldas/drought/). GLDAS output is produced as 3-hourly and monthly values and at $0.25-1^{\circ}$ resolution. Data are available from the NASA web site with around one month latency.

Two large-scale experimental operational hydrological monitoring and forecasting systems have been developed by Princeton University for the eastern USA (http://hydrology. princeton.edu/ luo/research/FORECAST/project.php) and by the University of Washington for the western USA (http://www.hydro.washington.edu/forecast/westwide/).

Both systems evolved from NLDAS, use the VIC model, and provide near-real time (latency around one day) spatial model estimates of soil moisture and snow water equivalent, as well as weekly streamflow at gauging locations. Components of the two systems are currently being merged to provide operational seasonal forecasts for the US through NCEP (E. F. Wood, personal communication, 2010).

The European Flood Alert System (EFAS; http://floods. jrc.ec.europa.eu/efas-flood-forecasts) uses a gridded catchment model (LISFLOOD; Van der Knijff et al., 2010) that is initialised using atmospheric conditions inferred from onground observations, near real-time satellite data and forecasts of precipitation, temperature and evaporation up to 15 days out (Thielen-del Pozo et al., 2009). The same system outputs are used to provide daily updates of soil moisture conditions at $0.05^{\circ}$ resolution through the European Drought Observatory (EDO; http://edo.jrc.ec.europa.eu/).

Apart from the discussed operational systems, some monitoring and forecasting systems exist that are not intended for water resources applications but nonetheless contain hydrological models or land surface models. An example is the experimental AWAP system (Australian Water Availability Project; Raupach et al., 2008; King et al., 2010) which provides monthly and weekly updates on soil moisture status for Australia at $0.05^{\circ}$ resolution (http://www.eoc.csiro.au/ awap/). Groundwater and flow routing are not represented, but the system has been shown to produce monthly estimates of runoff that show useful agreement with observed streamflow (Raupach et al., 2008).

Finally, various monitoring and warning systems exist that have relevance to water resources but do not use a dynamic spatial hydrological model. These include flood and drought monitoring systems based on atmospheric model output, data collected by in situ networks, satellite products, or a combination of these. Examples include the US Drought Monitor (http://watermonitor.gov/), Global Flood Detection System (http://www.gdacs.org/flooddetection/), Dartmouth Flood Observatory (http://www.dartmouth.edu/ floods/) and flood warning services in many countries (including Australia; http://www.bom.gov.au/hydro/flood/). These systems are beyond the scope of this paper.

\section{The Australian Water Resources Assessment (AWRA) system}

\subsection{Design}

The purpose of AWRA is to provide up-to-date, accurate and relevant information about the history, present state and future trajectory of the water balance, with sufficient detail to inform water resources management. Intended dissemination of the information is by BoM through occasional and 


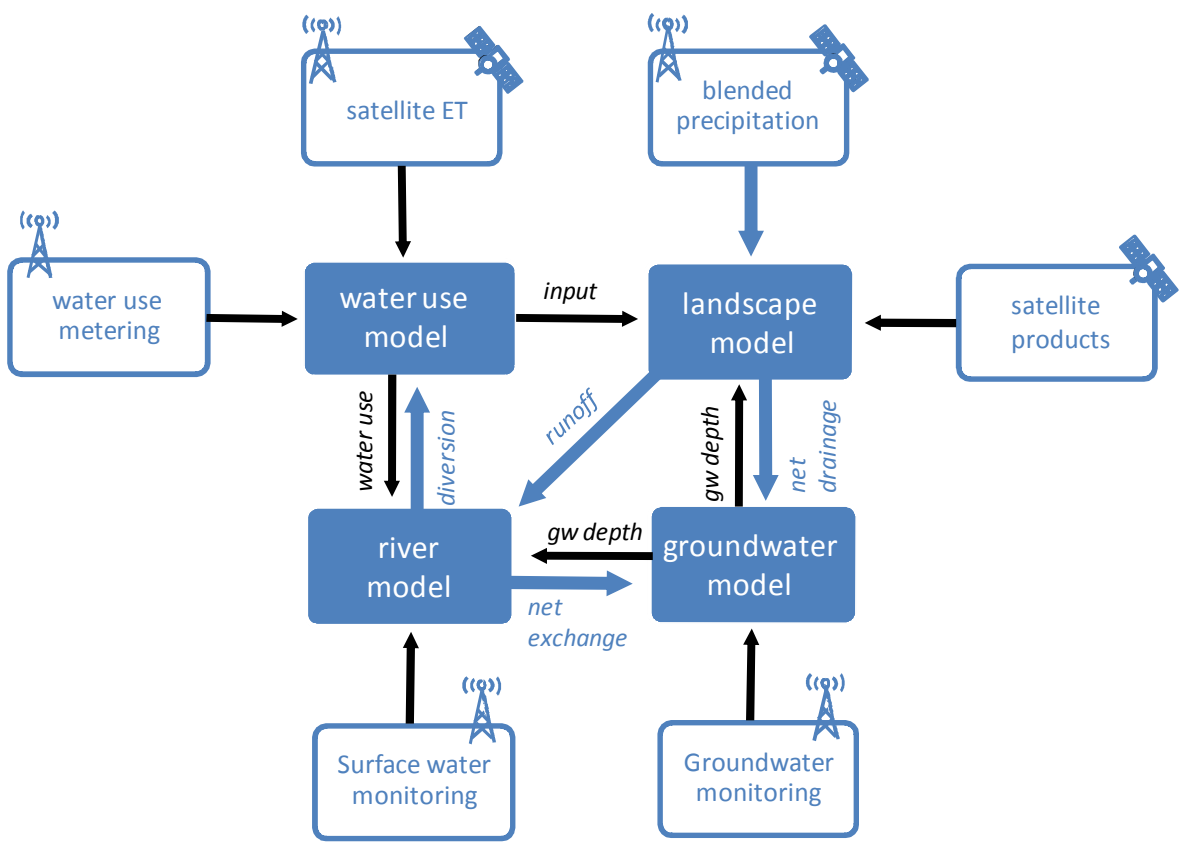

Fig. 1. Conceptual structure of the AWRA system showing the connections between models for the different hydrological processes, and the role of satellite and on-ground observations (indicated by the pictograms). Blue arrows indicate a water transfer from one model to another, black arrows indicates data flow through initialization or assimilation. Not all fluxes between models are shown and direction of water transfer can be reverse in some cases.

scheduled water resources assessments and the annual $\mathrm{Na}$ tional Water Account. The systems described in Sect. 2 provide important lessons but do not generally fulfil all requirements.

First, regulated and unregulated redistribution through surface water and groundwater systems forms the primary focus of water resources management and needs to be represented explicitly and accurately. Features that need to be described include irrigation, off-reach wetlands, floodplain inundation, surface water-groundwater exchanges, groundwater discharge to the soil, and the dynamic behaviour of water stored in public and private reservoirs and other water bodies. Except for the NHI, current SWRMS do not describe these processes and therefore additional development is required. This is achieved by coupling the spatial landscape hydrological model to lumped river models as well as lumped or distributed groundwater models, where required. In addition, surface and groundwater water extraction metering data are combined with satellite ET estimates to synthesise spatial information on water use (Fig. 1).

Second, the system needs to achieve estimates of riverand groundwater balance terms that are as good as those achieved with "conventional" hydrological tools, and preferably better. Tools widely used in Australia include lumped rainfall-runoff tools to estimate streamflow (e.g. Sacramento; Burnash et al., 1973); rational methods to estimate land cover effects on ET (Zhang et al., 2001); and soil-vegetationatmosphere models such as WAVES (Zhang and Dawes,
1998) to estimate groundwater recharge. These models are often simpler than LSMs and only target specific water balance terms and time scales, but they have been more comprehensively compared against field observations and are trusted by water resource managers. Their performance sets a benchmark in system development.

Third, the on-ground hydrometric network of streamflow and water level gauges, groundwater monitoring wells and diversion and extraction meters needs to be integrated with the model. For example, lumped rainfall-runoff models tend to be amenable to optimisation of a small number of (nondistributed) parameters to observed streamflow, and these parameter sets can have predictive value in nearby catchments as well (Chiew, 2010). Achieving similar performance in distributed models requires some of these parameterisation techniques to be used. Moreover, in water accounting hydrometric observations and model estimates will need to be reconciled. This introduces a need for model-data fusion techniques that do not only integrate satellite observations, but also on-ground observations.

Fourth, the information needs to have sufficient spatial resolution for water resources applications. Some processes or features tend to occur at resolutions lower than those considered in LSMs; for example irrigation, surface water bodies, floodplains and wetlands, and residential water use. In theory, there is high resolution satellite data to provide information on these features at very high $(<50 \mathrm{~m})$ resolution. In practice, it is currently not feasible computationally 
to model at this resolution over areas as large as Australia (7.7 million $\mathrm{km}^{2}$ ).

To address these challenges, the AWRA system has conceptually been designed as a modular system with four components (Fig. 1): (1) a grid-based, one-dimensional landscape hydrological model (AWRA-L; Sect. 3.2) that shows similarities to both LSMs and conventional hydrological tools; (2) a lumped model describing the river and floodplain water balance and routing; (3) lumped or finite element aquifer models for regions where groundwater dynamics are not well described by the landscape model (high transmissivity regional groundwater systems, floodplain aquifers); and (4) a water use model that uses metering and gridded satellite ET estimates to spatially infer lateral inflow derived from the river and groundwater systems (Van Dijk and Renzullo, 2009b).

The two-way coupling between these four models needs to be described in a way that is practical for operational application. This currently rules out fully-dynamic coupling. Instead, initialisation and data assimilation approaches are being developed to reconcile component models. These estimates are subsequently reconciled within the landscape and river water balance models through data assimilation in model re-analysis. These components and exchanges are currently still in development and not implemented operationally. The focus of satellite data use is in the AWRA landscape hydrological model, which is operational and described below.

\subsection{AWRA Landscape model}

The design of the AWRA Landscape (AWRA-L) model reflects a desire for parsimony - from a computational perspective, to achieve operational robustness (e.g., numerical model solutions requiring iteration were avoided), and from a scientific perspective, to reduce parameter uncertainty (or equifinality; Beven and Binley, 1992; Beven, 1989). The choices made in model formulation do sometimes represent a compromise between the aim for parsimony and the need to simulate variables that can be assimilated or that are required for reporting purposes (e.g. in the National Water Accounts; Bureau of Meteorology, 2010). As all AWRA components, AWRA-L has been designed as modular software, so that process descriptions are easily included, replaced and removed.

The current model version 0.5 is described in a report (Van Dijk, 2010a) and summarised briefly here. The AWRA-L structure may be described as a hybrid between a simplified "tiled" (sensu Avissar and Pielke, 1989) LSM and a lumped catchment model applied at grid resolution (cf. Chiew, 2010). Effectively, each grid cell is conceptualised as a catchment (or several identical catchments in parallel) that does not laterally exchange water with neighbouring cells. The validity of this assumption will vary as a function of model resolution, geohydrological conditions, and time scale. Grid reso- lution, domain and the number of sub-grid land cover classes (Hydrological Response Units; HRUs) are not prescribed but defined by the model inputs. The version implemented in the experimental AWRA system uses Australia-wide forcing data at $0.05^{\circ}$ resolution and considers two HRUs; deeprooted vegetation and shallow-rooted vegetation.

The model evolves on a daily time step. The water balance of a top soil, shallow soil and deep soil compartment are simulated for each HRU and groundwater and surface water dynamics are simulated at grid resolution. Simple and where available well-established equations were used to describe processes determining the radiation, energy and water balance. Evapotranspiration (ET) can be estimated following the Penman-Monteith equation or the Priestley-Taylor equation (Priestley and Taylor, 1972; Monteith, 1965), depending mainly on the availability of wind speed data. Storm and baseflow generation equations were selected after an evaluation of alternatives against streamflow observations (Van Dijk, 2009, 2010b). A simplified soil water hydraulics scheme that has minimal computational demands was derived empirically from simulations with a detailed model using Richards' equation. New approaches were developed to describe surface albedo dynamics and vegetation phenological response to water availability (Van Dijk, 2010a)

All HRU and catchment parameters can be prescribed as uniform values or as spatially-varying grids. Prior estimates for all parameters were based on literature review or analyses carried out as part of model development. The minimum meteorological inputs are daily gridded precipitation, incoming short-wave radiation and daytime average or maximum and minimum temperature. Where daily or daytime wind speed, vapour pressure and air pressure data are available they can be used optionally.

AWRA-L simulations have been compared against various in situ and satellite observations to assess performance in the absence calibration or assimilation. Satellite observations used for model evaluation are discussed in Sect. 4.4. In situ observations included streamflow measurements from 362 small Australian catchments affected minimally by regulation and flux tower ET observations at four sites across Australia (Van Dijk and Warren, 2010). Flux tower ET for dry canopy conditions was reproduced well; the main source of error was found to be caused by differences between tower-based precipitation measurements and grid-based estimates. Comparison of total ET was difficult due to the large uncertainty in rainfall interception evaporation estimated from the flux tower measurements. Streamflow records were reproduced with very similar accuracy to that achieved by lumped rainfall-runoff models in the absence of calibration. Simulations are likely to be improved by applying more advanced parameter calibration developed for such models (Chiew, 2010), particularly at smaller spatial and temporal scales. 


\subsection{Operational implementation}

As part of operational trialling, two experimental AWRA systems have been implemented, using respectively the ICT frameworks developed for the AWAP system (King et al., 2010) and Delft-FEWS (Werner and Whitfield, 2007). Both systems use $0.05^{\circ}$ resolution forcing data of daily precipitation, short-wave radiation, and minimum and maximum temperatures produced by the BoM. The precipitation fields are derived by interpolation of gauge observations only and are produced in a staged manner as observations with increasing latency become available (Jones et al., 2009). Minimum and maximum temperature fields are also derived by interpolation of station observations (Jones et al., 2009). Incoming short-wave radiation is estimated by blending station observations and geostationary measurements (see Sect. 4.2).

Satellite observations were used to estimate HRU fractions and some of the parameter fields (see Sect. 4.3). The operational AWRA-L model has not yet undergone any automated parameter optimisation. Simple observational models have been implemented to facilitate data assimilation for state updating (see Sect. 4.5) but data assimilation is currently not implemented operationally.

Outputs produced include gridded fields of water storage in the three soil compartments and groundwater, ET, streamflow generation, groundwater recharge. In addition some variables are produced for diagnostic purposes and as a precursor to operational data assimilation. These include vegetation biomass and leaf area index (LAI), and "synthetic" satellite observations such as fractional cover, vegetation greenness indices, soil surface wetness, and total column terrestrial water storage. An example output is shown in Fig. 2.

\section{Operational use of satellite observations}

\subsection{Utility of satellite observations}

Several papers have surveyed the potential or actual uses of satellite observations in hydrology (Schultz and Engman, 2000; Wagner et al., 2009; Fernández Prieto et al., 2009; Schmugge et al., 2002; Rango and Shalaby, 1998). They are summarised here with a focus on use in SWRMS and compared to the ground observations currently used in hydrological modelling (Fig. 3).

\section{- Atmosphere:}

Conventionally, the atmospheric variables that are required as forcing for hydrological models are precipitation gauge and weather station observations or derived interpolation products. Particularly in data sparse regions, satellite observations can help improve the quality of these inputs, for example by blending precipitation gauge information with rainfall radar and multisatellite rainfall products; and combining satellite observations of cloud cover, atmospheric composition and

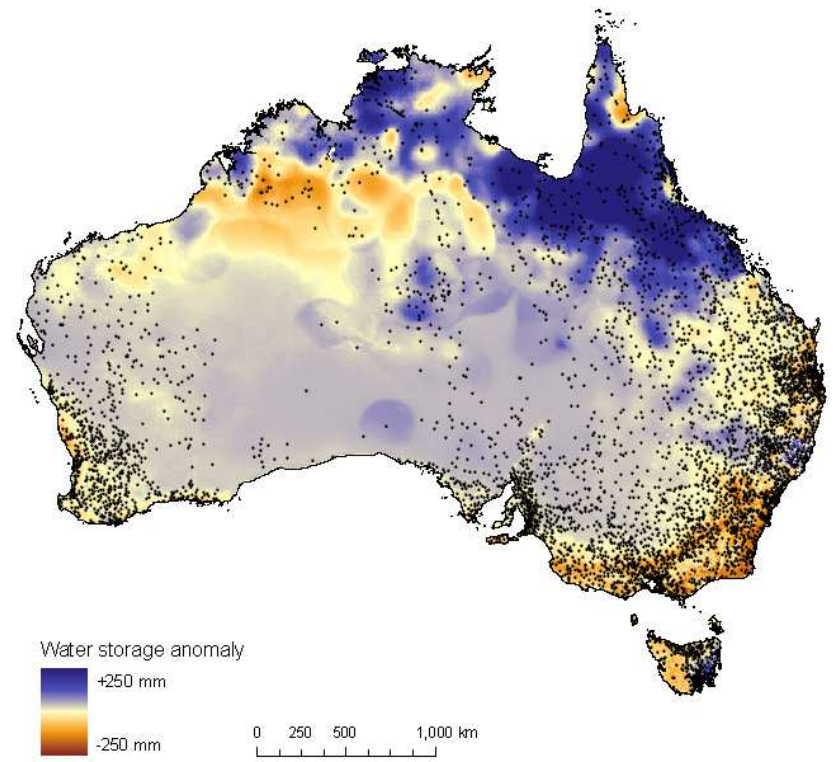

Fig. 2. Total water storage anomaly map for 1 February 2010, including water in the vegetation, soil, ground water and surface storages. Anomalies are calculated with reference to the average for the same day in the years 1980-2009. Points indicate the location of rain gauges used in the derivation of the interpolated model forcing.

temperature with weather station observations and/or NWP models.

- Vegetation and snow:

Optical and passive microwave observations can produce estimates of snow cover and snow water equivalent water storage, which can be used to initialise hydrological models. Optical satellite observations can be used to classify the landscape into land cover classes. Optical observations of albedo and thermal infrared (TIR) and microwave brightness temperatures or derived land surface temperatures (LSTs) can be assimilated into surface radiation and energy balance models to improve the accuracy of ET estimates. Similarly, optical observations of vegetation greenness and derived products such as the fraction of absorbed photosynthetically active radiation (FPAR) and leaf area index, and passive or active microwave derived estimates of vegetation water content, biomass and vegetation structure, can be used to estimate such variables as emissivity, canopy conductance and vegetation roughness, which affect the partitioning of radiation into ET and other terms.

- Soil:

Active and passive microwave observations have been used to estimate the topsoil moisture content, and the temporal decay in soil (brightness) temperature observations has been used to estimate soil hydraulic properties. 


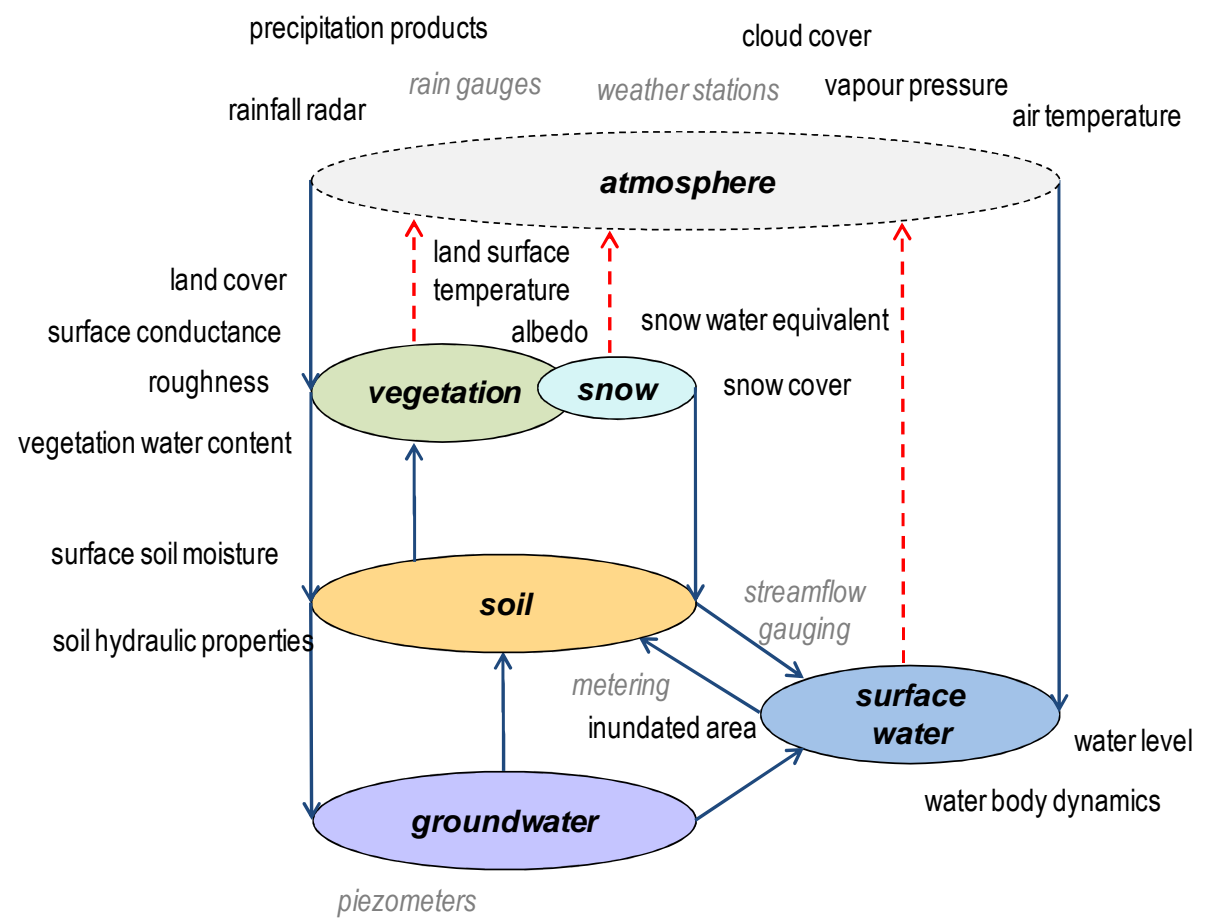

gravity anomaly

Fig. 3. Diagram showing the potential ways in which satellite observations can inform water resource assessment systems. Conventionally used on-ground observations are listed in italics.

- Surface water:

Satellite altimetry can be used to measure water level in larger water bodies, and optical active and passive microwave remote sensing have been applied to monitor the extent of water bodies and floods, as well as volume (through combination with elevation data).

\section{- Groundwater:}

While optical and microwave observations are too superficial to produce much information on groundwater dynamics, they have been used interpretatively in geohydrological mapping, and the occurrence of thermal anomalies can indicate groundwater discharge zones.

Finally, gravity measurements such as those by the Gravity Recovery and Climate (GRACE; Tapley et al., 2004) provide observations of total column water storage, which includes water in all stores mentioned above. Despite their currently coarse spatial resolution, they are a unique integrated measurement and have proven valuable for evaluation of large scale hydrological models.

This brief summary shows a wealth of possibilities for satellite observations to aid in hydrological modelling, including "soft" or interpretative uses (e.g., mapping, evaluation) as well as "hard" or quantitative uses (as model input or in data assimilation). Below, we review published operational and experimental uses of these observations, making a distinction between the use of satellite products for (1) dy- namic forcing; (2) a priori parameter estimation; (3) model evaluation and development; and (4) data assimilation, including both non-sequential techniques (such as parameter calibration) and sequential techniques (i.e., state updating).

\subsection{Dynamic forcing}

Several NWP systems routinely assimilate satellite observations and their products make their way into some of the operational systems that use weather analysis data and forecasts. For example, the NLDAS system uses daily gridded $0.25^{\circ}$ resolution precipitation estimated by interpolation of data from 6500 gauges measured in near-real time and 13000 gauges with greater latency; these data are interpolated to $0.125^{\circ}$ resolution and subsequently disaggregated to hourly estimates using rainfall radar observations (Cosgrove et al., 2003). Geostationary satellite observations are used to estimate incoming shortwave radiation at $0.5^{\circ}$ resolution. Other atmospheric variables (e.g. humidity, temperature, wind) are derived from NCEP NWP analysis (Cosgrove et al., 2003). The GLDAS system uses 2-hourly meteorological forcing derived from the NCEP global data assimilation system (GDAS) as a default. Precipitation is estimated from global $2.5^{\circ}$ resolution 5-day precipitation fields derived retrospectively by blending gauge and satellite observations (CMAP; Xie and Arkin, 1997) that are disaggregated in time and space using GDAS precipitation fields. Radiation 
is based on a $0.25^{\circ}$ resolution global satellite cloud cover product (Rodell et al., 2004). The two experimental seasonal forecasting systems for the USA use NLDAS forcing data for initialisation, augmented by non-operational station data for the western USA (E. F. Wood, personal communication, 2010. EFAS uses near-real time meteorological data based on approximately 2000 weather stations around Europe and available with 1 day latency. NHI uses precipitation forcing that includes $1 \mathrm{~km}$ radar derived rainfall fields and observations from 325 gauges.

The AWAP and AWRA systems both use $0.05^{\circ}$ resolution gridded fields of daily rainfall and temperature based on interpolated station data only (Jones et al., 2009). Satellite observations are however used in the operational estimation of incoming shortwave radiation, by combining solar reflective measurements from imagers aboard the Japanese GMS and MTSAT-IR geostationary satellites with station-level radiation measurements (Weymouth and Le Marshall, 2001).

The quality and resolution of precipitation data is recognised as one of the main limitations on useful hydrological monitoring (Nijssen et al., 2001). An important aspect of AWRA development has been the generation of better quality precipitation fields, in terms of spatial and temporal resolution as well as in accuracy. In several regions the density of stations is very low and consequently interpolation uncertainty large (cf. Fig. 2). The global Tropical Rainfall Measuring Mission (TRMM) Multi-satellite Precipitation Analysis (TMPA 3B42; Huffman et al., 2007) is a product that extends back to 1998. Only a subset of the Australian station network is used for bias correction in the product. Alternative statistical approaches to blending station data and satellite rainfall products have been explored. Li and Shao (2010) tested ordinary kriging and co-kriging with the TMPA data as a covariate, and developed a double kernel-smoothing technique to blend the two rainfall data sets. An example of the kernelbased blended rainfall estimate for Australia is given in Fig. 4 along with gauge-only analysis generated by the BoM and daily accumulation computed from the TMPA 3B42 rain rates. Cross validation suggested that among the approaches tested the double smoothing technique produced the lowest standard error and bias. The degree to which the resulting blended precipitation product improves AWRA estimates is currently being tested.

\section{Opportunities and challenges}

Opportunities for further development include the use of alternative satellite precipitation products (e.g. Joyce et al., 2004) in blending, as well as additional data sources such as NWP analysis data and rainfall radar. These data sources may facilitate the generation of informative estimates of subdaily rainfall distribution. Rainfall intensity is known to influence processes such as overland flow generation and rainfall interception losses, and there is reason to assume that a significant fraction of the differences between model es-

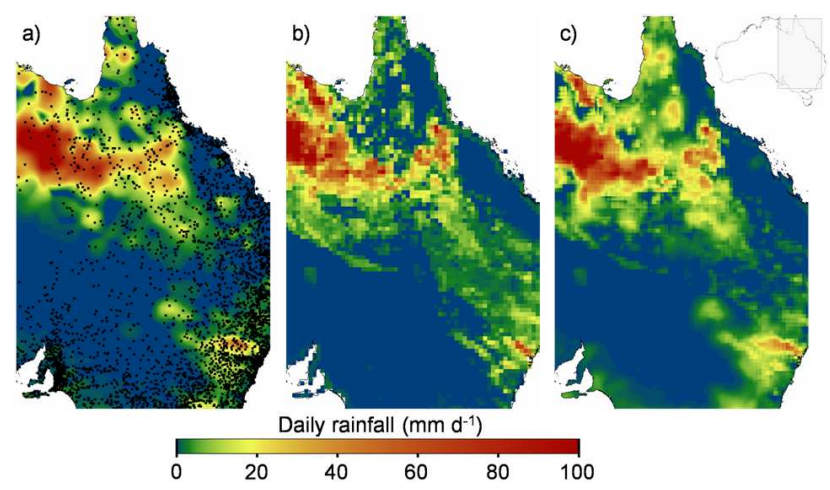

Fig. 4. Daily rainfall estimates for 5 January 2005: (a) gauge-only analysis (Jones et al., 2009) (black dots represent gauge locations); (b) 24-h accumulations of satellite-based TMPA 3B42 rain rates; and (c) blended satellite-gauge rainfall estimate generate using the kernel-based algorithm of Li and Shao (2010).

timated and observed peak streamflow is due to these processes (Van Dijk, 2010b; Giannoni et al., 2003).

There are also challenges to be addressed when using satellite data to generate dynamic forcing operationally. In particular, caution needs to be taken when ingesting a product for which continuity is not assured, or the quality of which relies on research missions (the TMPA product is a case in point). Another challenge is the need to understand the error in gauge records as well as satellite products, and temporal and spatial scaling between the two.

\subsection{A priori parameter estimation}

The adjective a priori is used here to distinguish those parameters estimated in independent data analysis or heuristics from those obtained via formal model optimisation (see Sect. 4.5).

There are several examples of the use of satellite observations and derived products to parameterise hydrological models. The most common use is for land cover classification and to prescribe vegetation canopy structural and biophysical properties. Both NLDAS and GLDAS use a 1-km resolution 13-class land cover data set derived from AVHRR (Hansen et al., 2000). The different models in NLDAS use different approaches to prescribing an LAI or canopy fraction climatology, but all are based on AVHRR NDVI data (see Mitchell et al., 2004 for details). GLDAS, too, uses AVHRR NDVI observations to produce gridded LAI climatologies for the various land cover classes using a procedure described in Rodell et al. (2004) and Gottschalck et al. (2002). The LISFLOOD model in EFAS uses a classification based on a blend of AVHRR (Mucher et al., 2000) and SPOT/VEGETATION (Bartholomé and Belward, 2005) derived products; monthly LAI estimates are derived from SPOT/VEGETATION and ATSR/AATSR (Garrigues et al., 2008). AWAP uses NDVI and FPAR derived from SeaWiFS (Gobron et al., 2002). 
In AWRA, grid cell fractions of deep- and shallowrooted vegetations are estimated from persistent and recurrent greenness fractions based on AVHRR NDVI observations (Donohue et al., 2009). MODIS albedo and vegetation properties (Knyazikhin et al., 1999; Myneni et al., 2002; Schaaf et al., 2002) were also used to derive parameters describing the interrelationships between LAI, fraction canopy cover and albedo, whilst a photosynthetic capacity index was calculated from the enhanced vegetation index (EVI; Huete et al., 2002) and used to estimate surface conductance. Finally, ENVISAT ASAR GM radar (Pathe et al., 2009) observations were used to derive parameters describing the relationship between topsoil moisture content and soil albedo (Van Dijk, 2010a). Canopy dynamics are explicitly simulated by the model and satellite vegetation climatology is not used operationally.

\section{Opportunities and challenges}

There are many opportunities for greater use of satellite observations to derive spatially continuous fields of soil and vegetation parameters. Examples include the use of multiand hyperspectral data to estimate canopy assimilative capacity and/or water content and thereby surface conductance (Guerschman et al., 2009; Glenn et al., 2008); the use of radar and microwave data to parameterise vegetation biomass or water content (Meesters et al., 2005), height (Kellndorfer et al., 2004) and aerodynamic roughness (Prigent et al., 2005). Satellite albedo products can improve radiation balance estimates which can help hydrological estimation. Finally, it has been shown feasible to estimate soil hydraulic properties with the aid of temporal patterns in remotely-sensed temperatures or soil moisture or ET products (Mattikalli et al., 1998), although this is perhaps better approached through parameter optimisation techniques, given the influence of forcing on the temporal behaviour of these variables (Gutmann and Small, 2010; Pauwels et al., 2009; and references therein).

There are also some difficult challenges in the inference of vegetation and soil parameter fields. All biophysical properties (e.g. LAI, albedo, biomass) are inferred from remote sensing and are thus subject to uncertainties in the parameters and assumptions of the retrieval model (e.g. Glenn et al., 2008). In addition, there can be conceptual differences between variables that are superficially similar between remote sensing products and models. Examples include the difference between FPAR and fraction canopy cover, between optical depth and biomass, and between remotely-sensed surface soil properties and desired integrated soil properties.

\subsection{Model evaluation and improvement}

While not essential to support an operational system, satellite observations can be useful to evaluate the performance of hydrological models. Evaluation can help to (1) set a benchmark against which future modifications can be tested; (2) understand how and against which observations model estimates are most usefully compared; (3) identify processes or quantities that are not described well by the model; (4) inform the development of model-data assimilation techniques; and (5) allow the model results to be used with appropriate caveats and "fit for purpose" disclaimers.

Several SWRMS have undergone evaluation against satellite observations. Such evaluations are usually included when testing the performance of satellite data assimilation techniques (e.g. as "open loop" estimates; see Sect. 4.5). For example, NLDAS LST simulations were compared to GOES satellite LST fields (Mitchell et al., 2004) and Laguardia and Niemeyer (2008) compared soil moisture simulations by the EFAS/LISFLOOD system against ERS radar derived soil moisture. There have also been numerous studies using satellite observations to evaluate results from non-operational hydrological models. For example, Kite and Droogers (2000) compared several hydrological models and satellite-based ET estimation methods, as well as field measurements. Spatial soil moisture fields derived from hydrological models have been compared to estimates derived from passive microwave observations (Liu et al., 2010) and radar (Vischel et al., 2008; Parajka et al., 2009). Biftu and Gan (2001) used AVHRR and Landsat LST and radar soil moisture to evaluate model results. GRACE observations have been used to evaluate simulated total water storage in several studies (see reviews by Güntner, 2008; Ramillien et al., 2008).

AWRA simulations have been assessed against satellitederived estimates of topsoil moisture content, surface and vegetation properties (fraction cover, FPAR, EVI), total terrestrial water storage, and ET estimates. Topsoil moisture derived from ENVISAT/ASAR GM showed spatial patterns that corresponded well with independent satellite product error estimates (Pathe et al., 2009; Van Dijk, 2010a; Doubkova et al., 2010). AVHRR- and MODIS-derived estimates of FPAR, canopy cover fraction and greenness were reproduced well for seasonal vegetation that responds dynamically to water availability, while temperature driven phenology and small variations in canopy properties for evergreen forests were not reproduced. AWRA simulated total terrestrial water storages have also been evaluated against GRACE-derived terrestrial water storage estimates (Van Dijk and Renzullo, 2009a).This showed generally good agreement in the dynamic range and patterns (Fig. 5) and emphasised the utility of satellite gravity observations to identify errors in forcing and the model description of soil and groundwater dynamics, even if currently only at coarse scale.

More recently, evaluation against MODIS albedo (Schaaf et al., 2002) has proven useful in assessing where the model 

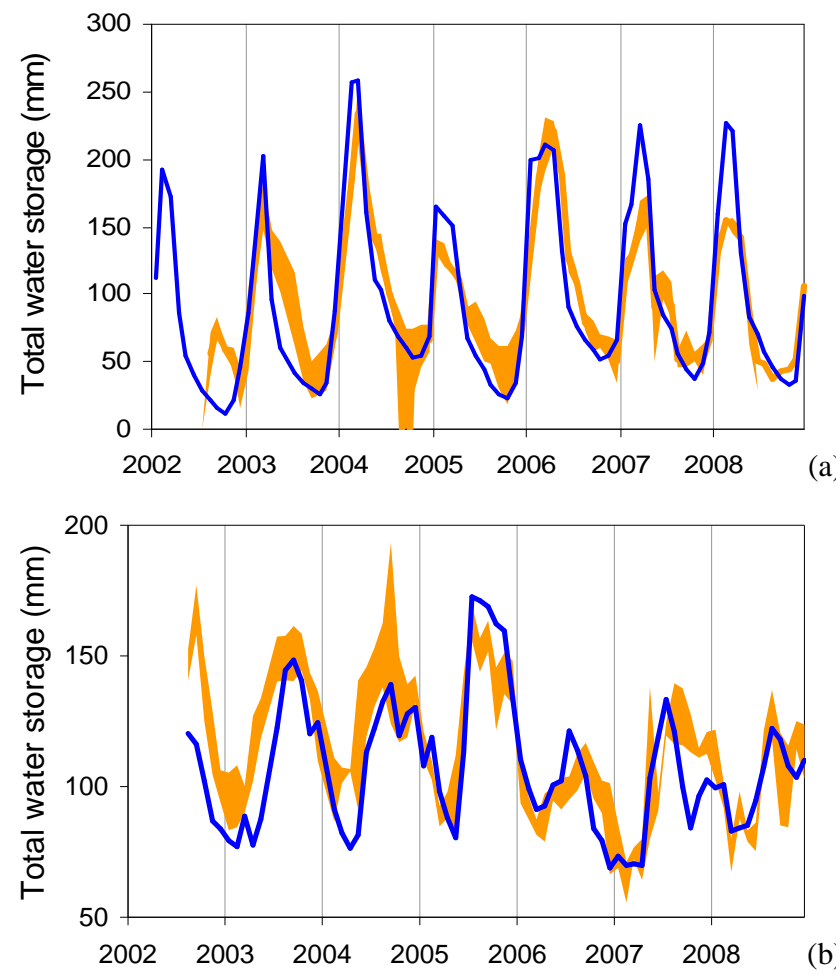

Fig. 5. Comparison of large scale average TWS derived from three GRACE products (orange band) and AWRA (blue line) for the (a) Timor sea drainage division, and the (b) Murray Basin.

performs better than a climatology (Van Dijk et al., 2010); and evaluation against AMSR-E and TRMM derived soil moisture products (Liu, 2008) along with radar based estimates and in situ observations has helped to assess optimal soil moisture blending methods (Liu et al., 2010). Comparison against a MODIS reflectance-based scaling ET product (Guerschman et al., 2009) has allowed the mapping of areas where lateral inflows of river or groundwater occur (Van Dijk et al., 2010).

\section{Opportunities and challenges}

Where systematic differences are observed and can be attributed to model error, this can subsequently lead to improvements in model structure or parameterization. Several model inter-comparison experiments have been undertaken in order to assess alternative modelling approaches, although interpretation tends to be confounded by the inability to ascribe observed performance differences to forcing, parameters and model structure (e.g. Dirmeyer et al., 2006; Fox et al., 2006; Henderson-Sellers et al., 1995). An additional challenge in using satellite retrieved data can be the uncertainty introduced by the retrieval model. It has frequently been suggested to the authors that an evaluation against satellite retrieved products is not strictly valid, as it constitutes "a comparison of models against models". While some re- trieval methods indeed rely on pragmatic but, strictly speaking, wrong assumptions and/or unknown or uncertain model parameters, this ignores the fact that the estimation of biophysical fluxes from field measurements also requires processing that can equally introduce large uncertainties. Examples include the potential for large errors in the discharge rating curve to convert water level to streamflow; and the various corrections and gap-filling required to estimate ET from flux tower measurements. A distinct additional disadvantage of field observations can be the uncertainty when scaling these observations to model resolution. In fact it has been argued that satellite ET algorithms have reached an accuracy that is on par with flux tower techniques (Guerschman et al., 2009; Van Dijk and Warren, 2010).

\subsection{Data assimilation}

Data assimilation here includes all computational techniques used to minimise differences between modelled and observed variables, including non-sequential techniques such as parameter calibration (or "tuning") and sequential state updating techniques.

The use of hydrometric observations to calibrate hydrological models is well established, but the use of satellite observations to estimate parameters in spatially-distributed hydrological models is less common. A challenge is the computational burden of finding an optimal parameter set for each model unit (e.g. grid cell-HRU combination). Existing examples appear to be restricted to research studies. For example, Kalma et al. (2008) reviewed some uses of LST observations to calibrate LSMs, and additional studies have been published since (Winsemius et al., 2008; Renzullo et al., 2008; Immerzeel and Droogers, 2008; Droogers et al., 2010). Campo et al. (2006) and Parajka et al. (2009) attempted the use of radar soil moisture retrievals to calibrate hydrological models. GRACE data were included in multi-objective parameter optimization approaches to constrain groundwater hydrological parameters (Lo et al., 2010).

In models with a large number of modelling units (e.g. grid cells), state updating can require fewer model iterations than parameter optimization and hence be more attractive for operational applications. Operational satellite-based state updating in NWP has existed since the 1970s and has improved the accuracy of short ( $<7$ day) term forecasts remarkably (Simmons and Hollingsworth, 2002) and continues to do so (Poli, 2010). Common approaches include optimal interpolation, three- and four-dimensional variational techniques (Bouttier and Courtier, 1999; Kalnay, 2003). Apart from the use of remotely-sensed LAI time series, operational assimilation in hydrological models appears to be limited to the GLDAS system. GLDAS assimilates sub-daily LST from TIROS/TOVS geostationary observations (Ottlé and VidalMadjar, 1992) by optimal interpolation and assimilates a MODIS snow cover product (Hall et al., 2002) using a rulebased algorithm. Experiments have been done to assimilate 

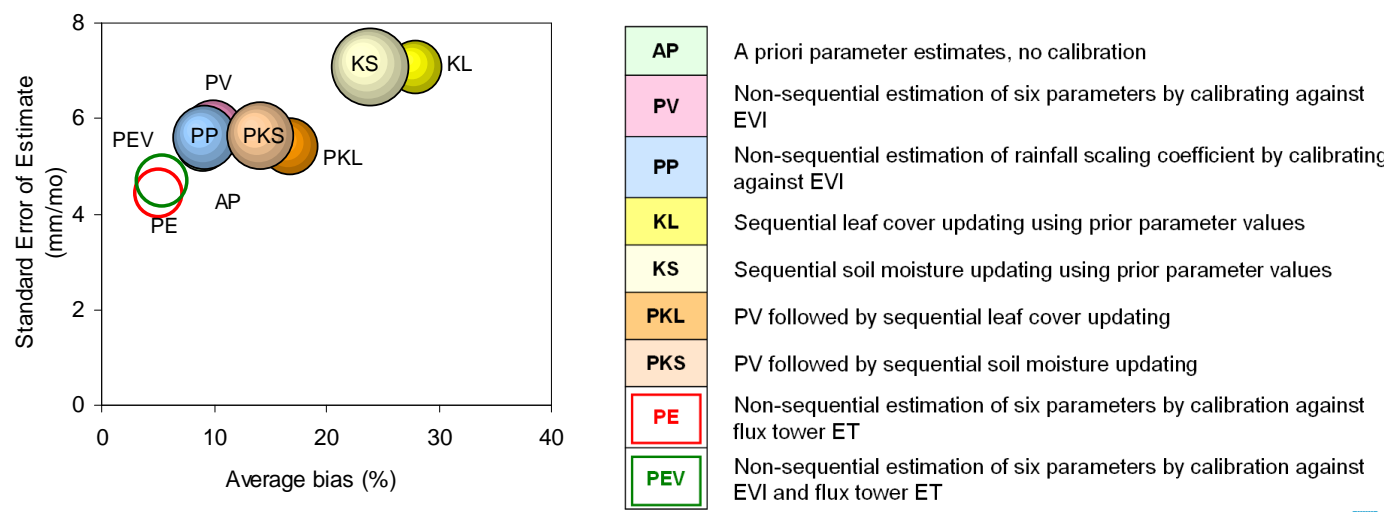

Fig. 6. Indicators of estimation uncertainty for alternative model-data fusion approaches for flux tower ET (the area of the circles is proportional to the unexplained variance, varying between 11-17\%). The most desirable result would show a small circle in lower left corner. Note that the absolute value of bias for each site was calculated before averaging.

passive microwave derived soil moisture and GRACE observations but these have not yet been implemented operationally (Rodell et al., 2004; Zaitchik et al., 2008). Similarly, experiments have been done to assimilate remotely-sensed snow cover and microwave brightness temperature (Pan et al., 2009; Andreadis and Lettenmaier, 2006).

There are several more published off-line data assimilation experiments. The assimilation of satellite observations such as LST and microwave brightness temperature has typically involved LSMs rather than models with a hydrological lineage (Troch et al., 2003). Probably an important reason has been that assimilation of radiances and surface temperatures requires description of the diurnal surface radiation and energy balance; consideration of atmospheric transmissivity on sensor observations; and a model structure and ICT infrastructure that facilitate (gridded) data assimilation - all of which are available within NWPs but not usually in hydrological models. One of the first studies attempting assimilation of satellite observations into a conventional hydrological model was Ottlé and Vidal-Madjar (1994), who used AVHRR-derived LST and NDVI to update a rainfallrunoff model. Houser et al. (1998) were among the first to use brightness temperature to improve soil moisture estimation in a distributed hydrological model. More straightforward in hydrological models is the assimilation of satellite derived products. So far, research results have been inconclusive as to whether assimilating remotely-sensed soil moisture products improves estimates of streamflow; some studies found improvements (Francois et al., 2003; Pauwels et al., 2002) while others obtained mixed or unsatisfactory results (Parajka et al., 2006; Crow et al., 2005). Other assimilation experiments with distributed hydrological models have used Landsat LST-derived ET (Schuurmans et al., 2003; Qin et al., 2008), Landsat and SPOT derived LAI (Boegh et al., 2004), and both MODIS LAI and LST-derived ET (Vazifedoust et al., 2009).
AWRA currently does not assimilate satellite observations, but some assimilation experiments have been done to guide implementation. The effectiveness of assimilating MODIS Enhanced Vegetation Index (EVI) (Huete et al., 2002) observations into AWRA was tested at four flux tower sites (Van Dijk and Renzullo, 2009c). Approaches tested include non-sequential parameter optimisation of, respectively, six sensitive model parameters (calibration against EVI, and for comparison against ET or both EVI and ET) or a single rainfall scaling factor. An ensemble Kalman filter was applied for sequential updating of either LAI or soil moisture, respectively. Performance was evaluated in terms of standard error, bias and the fraction of variance left unexplained, using daily flux tower ET estimates as well as passive microwave derived soil moisture for the site (Liu et al., 2007). The approaches are summarised and results shown in Fig. 6.

Prior model parameter estimates already appear to produce quite good estimates of ET. For these sites, parameter estimation did not appear to provide much benefit compared to using prior parameter estimates. A combination of parameter estimation and state updating led to a small $(<6 \%)$ improvements in some aspects of ET evaluation when compared to using a priori parameter estimates. However it was also about three orders of magnitude more computationally intensive, as six parameters first needed to be simultaneously optimised, and subsequently a 100-member ensemble propagated. Parameter optimisation and Kalman filtering combined also led to very small improvements in the agreement with soil moisture (Van Dijk and Renzullo, 2009c). The quality of rainfall forcing was an important factor in the unexplained variance, which was confirmed in evaluation of offline AWRA-L model simulations against observations (Van Dijk and Warren, 2010). It is noted that none of the sites underwent disturbances during the one- to four-year analysis period; assimilation would likely be more effective in areas undergoing vegetation change unrelated to water availability. 


\section{Opportunities and challenges}

The operational uses and published experiments of data assimilation emphasise that the greatest benefit can be expected where the model does not simulate processes well and observations are of sufficient accuracy and relevance to improve the analysis; that is, "good data can fix a bad model". The effectiveness of data assimilation hinges on the degree to which the target variables are influenced by the processes improved by assimilation. For example, satellite observations of surface radiances may not help estimate hydrological processes that occur within small areas below satellite resolution (such as runoff from saturated zones) or that are more affected by unknown precipitation characteristics (such as spatial and temporal rainfall intensities in the case of infiltration excess runoff) or forcing errors (such as rainfall in sparsely gauged areas). Dominant runoff processes vary in response to climate and catchment conditions, and this may partly explain the variable effectiveness of soil moisture assimilation reported in literature. Similarly, because of the low importance of snow in Australia's water resources, AWRA-L does not simulate snow hydrological processes, nor would assimilation of snow observations improve water balance estimates except perhaps for a small fraction of the continent. On theoretical grounds (Budyko, 1974) the constraint imparted by different satellite observations can be predicted to be a function of climate wetness: where ET is only limited by available energy, radiation and energy balance measures such as albedo and surface roughness may be informative, although precipitation uncertainty may well be the greatest source of uncertainty in streamflow and recharge estimation. Where ET is limited by water availability, observations of soil moisture and vegetation are likely to be informative, and can possibly even be used to correct errors in precipitation estimates (Crow et al., 2009; Crow and Ryu, 2009). The information content of observations also varies as a function of transient vegetation and soil moisture conditions. Experiments with a precursor of AWRA-L indicated that microwave and TIR observations only impart useful information under certain conditions: microwave emissions are informative for topsoil wetness in sparsely vegetated areas, whereas TIR can constrain root-zone water content over vegetated areas (Barrett and Renzullo, 2009).

A second challenge is the observation model required to assimilate "raw" observations (that is, radiances, brightness temperatures and backscatter) rather than derived products. While assimilation of these original observations is desirable from a theoretical point of view, hydrological models typically require considerable extensions to produce forward estimates of these variables, with associated complexity, model structural errors and parameter uncertainties. This approach can also increase computational requirements and affect system robustness, for example where observations in several bands or polarisations simultaneously need to be assimilated. Assimilation of derived hydrological products can be more straightforward but tends to introduce errors through the poor specification of observational errors required for assimilation. A promising approach would be to use the product retrieval models to generate spatially and temporally explicit uncertainty bounds.

A third challenge is the assimilation of satellite observations obtained at scales coarser than the model resolution. Given the resolution required for useful water resources monitoring this is particularly the case for GRACE and passive microwave observations. Progress towards the development of operational approaches has been made (Pan et al., 2009; Zaitchik et al., 2008), but challenges remain, including a accurate specification of the footprint, and in the case of microwave observations, the development of methods to account for the non-linearity in scaling and the variable influence of surface water on the soil moisture retrieval.

A fourth challenge for operational application is the computational overheads that parameter optimisation and state updating can introduce. In particular, multi-dimensional parameter optimisation can require a very large number of iterations, and ensemble filtering approaches are computationally intensive (see Van Dijk and Renzullo, 2009c for an example).

\section{Conclusions}

Spatial water resource monitoring systems (SWRMS) can provide important benefits for water management. All major technological obstacles have been overcome to facilitate the development and operational deployment of such systems, and indeed some already exist, albeit as experimental services with limited scope. The Australian water resources assessment (AWRA) system is one such example and is introduced in this paper. In addition, the current state of operational SWRMS is surveyed, with an emphasis on the way in which satellite observations are used. The following conclusions are drawn:

1. Most operational SWRMS focus on the landscape component of the water cycle, in line with their heritage as land surface models (LSMs) in large scale weather and climate models. There is however convergence between these LSMs and water resource models.

2. Developments required to extend the use of current SWRMS approaches to a wider range of water management purposes include (a) explicit description of water redistribution and use in regulated and unregulated river systems and groundwater systems; (b) a performance against hydrometric observations that is equal or better than existing water resources models; (c) optimal use of these hydrometric observations to constrain estimates; and (d) higher spatial resolution. These developments require the coupling of landscape models with models describing surface water and groundwater dynamics and water use. 
3. Satellite observations of the atmosphere, vegetation, snow, soil, surface water and groundwater have the potential to improve the accuracy and spatial detail in SWRMS, and can be derived from multi-spectral measurements of reflectance, thermal and microwave emissions, radar backscatter, altimetry, and gravity measurements.

4. All existing SWRMS use some form of dynamic forcing derived by blending satellite and on-ground observations, through interpolation approaches or by using analysis outputs from NWPs. Opportunities exist to develop and use more accurate and higher spatial and temporal resolution precipitation products, but precipitation scaling and the operational reliability of these products need to be considered.

5. Satellite-derived land cover classification and vegetation dynamics are commonly used in SWRMS. Many opportunities exist for greater use of remote sensing products to provide a priori model parameter estimates related to vegetation biomass, albedo, roughness and conductance and soil hydraulic properties. This requires good understanding of conceptual differences between satellite products and their model equivalents.

6. Model evaluation against satellite observations provides unique spatial information on model output uncertainty, can help guide further improvement, and are a logical precursor to the development of model-data assimilation techniques. This does require a good quantitative understanding of errors in satellite retrievals, however.

7. Assimilation of satellite observations can be achieved through non-sequential techniques (such as parameter calibration) and sequential techniques (i.e., state updating). The utility of satellite observations through data assimilation also depends on dominant hydrological processes in the model domain and transient hydrological conditions. Furthermore, hydrological models are not always well equipped to assimilate "raw" satellite observations. Assimilation of derived hydrological variables may be more attractive but requires correct and detailed specification of retrieval error. Methods are also required to deal with the coarse resolution of passive microwave and gravity observations when compared to most SWRMS. Finally, the computational implications of data assimilation techniques due to the large number of modelling units and the potentially large number of iterations required needs to be carefully considered in operational implementation.
Acknowledgements. This work is part of the water information research and development alliance between the Bureau of Meteorology and CSIRO's Water for a Healthy Country Flagship. Comments from Matt Rodell, Jutta Thielen, Albrecht Weerts and Eric Wood and are gratefully acknowledged.

Edited by: P. van Oevelen

\section{References}

Andreadis, K. M. and Lettenmaier, D. P.: Assimilating remotely sensed snow observations into a macroscale hydrology model, Adv. Water Resour., 29, 872-886, 2006.

Avissar, R. and Pielke, R.: A parameterization of heterogeneous land surfaces for atmospheric numerical models and its impact on regional meteorology, Mon. Weather Rev., 117, 2113-2136, 1989.

Barrett, D. J. and Renzullo, L. J.: On the Efficacy of Combining Thermal and Microwave Satellite Data as Observational Constraints for Root-Zone Soil Moisture Estimation, J. Hydrometeorol., 10, 1109-1127, doi:10.1175/2009JHM1043.1, 2009.

Bartholomé, E. and Belward, A. S.: GLC2000: a new approach to global land cover mapping from Earth observation data, Int. J. Remote Sens., 26, 1959-1977, 2005.

Berendrecht, W., Weerts, A. H., Veldhuizen, A. A., and Kroon, T.: An operational drought forecasting system using coupled models for groundwater, surface water and unsaturated zone, ModelCARE 2009, Wuhan, China, 2009.

Beven, K.: Changing ideas in hydrology - The case of physicallybased models, J. Hydrol., 105, 157-172, 1989.

Beven, K. and Binley, A.: The future of distributed models: model calibration and uncertainty prediction, Hydrol. Process., 6, 279 298, 1992.

Biftu, G. and Gan, T.: Semi-distributed, physically based, hydrologic modeling of the Paddle River Basin, Alberta, using remotely sensed data, J. Hydrol., 244, 137-156, 2001.

Boegh, E., Thorsen, M., Butts, M. B., Hansen, S., Christiansen, J. S., Abrahamsen, P., Hasager, C. B., Jensen, N. O., van der Keur, P., Refsgaard, J. C., Schelde, K., Soegaard, H., and Thomsen, A.: Incorporating remote sensing data in physically based distributed agro-hydrological modelling, J. Hydrol., 287, 279-299, 2004.

Bouttier, F. and Courtier, P.: Data assimilation concepts and methods, ECMWF Meteorological Training Course Lecture Series, 14, 1999.

Budyko, M. I.: Climate and Life Academic Press, New York, 508 pp., 1974.

Bureau of Meteorology: Pilot National Water Account, Commonwealth of Australia, Melbourne, 359, 2010.

Burnash, R. J. C., Ferral, R. L., and McGuire, R. A.: A generalized streamflow simulation system: conceptual models for digital computers, J, Joint Federal-State River Forecast Center, Sacramento, California, 1973.

Campo, L., Caparrini, F., and Castelli, F.: Use of multi-platform, multi-temporal remote-sensing data for calibration of a distributed hydrological model: an application in the Arno basin, Italy, Hydrol. Process., 20, 2693-2712, 2006.

Chiew, F.: Lumped Conceptual Rainfall-Runoff Models and Simple Water Balance Methods: Overview and Applications in Un- 
gauged and Data Limited Regions, Geogr. Compass, 4, 206-225, 2010.

Cosgrove, B., Lohmann, D., Mitchell, K., Houser, P., Wood, E., Schaake, J., Robock, A., Marshall, C., Sheffield, J., and Duan, Q.: Real-time and retrospective forcing in the North American Land Data Assimilation System (NLDAS) project, J. Geophys. Res., 108, 8842, 2003.

Crawford, N., and Linsley, R.: Digital simulation in hydrology: Stanford watershed model IV, Dept. of Civil Engineering, Stanford University, 1966.

Crow, W., Huffman, G., Bindlish, R., and Jackson, T.: Improving satellite-based rainfall accumulation estimates using spaceborne surface soil moisture retrievals, J. Hydrometeorol., 10, 199-212, 2009.

Crow, W. T. and Ryu, D.: A new data assimilation approach for improving runoff prediction using remotely-sensed soil moisture retrievals, Hydrol. Earth Syst. Sci., 13, 1-16, doi:10.5194/hess13-1-2009, 2009.

Crow, W. T., Bindlish, R., and Jackson, T. J.: The added value of spaceborne passive microwave soil moisture retrievals for forecasting rainfall-runoff partitioning, Geophys. Res. Lett., 32, L18401, doi:10.1029/2005g1023543, 2005.

Dirmeyer, P. A., Gao, X., Zhao, M., Guo, Z., Oki, T., and Hanasaki, N.: The Second Global Soil Wetness Project (GSWP-2): Multimodel analysis and implications for our perception of the land surface, B. Am. Meteorol. Soc., 87, 1381-1397, 2006.

Döll, P., Kaspar, F., and Lehner, B.: A global hydrological model for deriving water availability indicators: model tuning and validation, J. Hydrol., 270, 105-134, 2003.

Donohue, R. J., McVicar, T. R., and Roderick, M. L.: Climaterelated changes in Australian vegetation cover as inferred from satellite observations for 1981-2006, Global Change Biol., 15, 1025-1039, doi:10.1111/j.1365-2486.2008.01746.x, 2009.

Droogers, P., Immerzeel, W. W., and Lorite, I. J.: Estimating actual irrigation application by remotely sensed evapotranspiration observations, Agr. Water Manage., 97, 1351-1359, 2010.

Fernández Prieto, D., Berry, P. A. M., Benveniste, J., Courault, D., Cretaux, J. F., Van Dijk, A. I. J. M., Doell, P., Gambacorta, A., De Jeu, R. A. M., Kerr, Y., Kidd, K., Koike, T., Kustas, W., Levizzani, V., McCabe, M. F., Montanari, A., Menenti, M., Njoku, E. G., van Oevelen, P., Prigent, C., Roebeling, R., Schulz, J., Su, Z. B., Wagner, W., and Wood, E.: Earth Observation and Water Cycle Science: towards a multi-mission observation strategy, Earth Observation and Water Cycle Science, Frascati, Italy, 1820 November, 2009.

Fox, S., Pitman, A. J., Boone, A., and Habets, F.: The Relationship between Intermodel Differences and Surface Energy Balance Complexity in the RhÃ'ne-Aggregation Intercomparison Project, J. Hydrometeorol., 7, 81-100, doi:10.1175/JHM475.1, 2006.

Francois, C., Quesney, A., and Ottlé, C.: Sequential Assimilation of ERS-1 SAR Data into a Coupled Land Surface-Hydrological Model Using an Extended Kalman Filter, J. Hydrometeorol., 4, 473-487, doi:10.1175/15257541(2003)4<473:SAOESD>2.0.CO2, 2003.

Freeze, R. A. and Harlan, R. L.: Blueprint for a physically-based, digitally-simulated hydrologic response model, J. Hydrol., 9, 237-258, 1969.

Garrigues, S., Lacaze, R., Baret, F., Morisette, J. T., Weiss, M.,
Nickeson, J. E., Fernandes, R., Plummer, S., Shabanov, N. V., Myneni, R. B., Knyazikhin, Y., and Yang, W.: Validation and intercomparison of global Leaf Area Index products derived from remote sensing data, J. Geophys. Res., 113, G02028, doi:10.1029/2007jg000635, 2008.

Giannoni, F., Smith, J., Zhang, Y., and Roth, G.: Hydrologic modeling of extreme floods using radar rainfall estimates, Adv. Water Resour., 26, 195-203, 2003.

Glenn, E., Huete, A., Nagler, P., and Nelson, S.: Relationship between remotely-sensed vegetation indices, canopy attributes and plant physiological processes: What vegetation indices can and cannot tell us about the landscape, Sensors, 8, 2136-2160, 2008.

Gobron, N., Pinty, B., Melin, F., Taberner, M., and Verstraete, M. M.: Sea Wide Field-of-View Sensor (SeaWiFS)-An optimized FAPAR algorithm-Theoretical Basis Document, EUR Report No. 20148 EN, Institute for Environment and Sustainability, 2002.

Gottschalck, J., Houser, P., and Zeng, X.: Impact of remotely sensed leaf area index on a global land data assimilation system, 16th Conference on Hydrology, Orlando, FL, 2002,

Guerschman, J.-P., Van Dijk, A. I. J. M., Mattersdorf, G., Beringer, J., Hutley, L. B., Leuning, R., Pipunic, R. C., and Sherman, B. S.: Scaling of potential evapotranspiration with MODIS data reproduces flux observations and catchment water balance observations across Australia, J. Hydrol., 369, 107-119, 2009.

Güntner, A.: Improvement of global hydrological models using GRACE data, Surv. Geophys., 29, 375-397, 2008.

Gutmann, E. D. and Small, E. E.: A method for the determination of the hydraulic properties of soil from MODIS surface temperature for use in land-surface models, Water Resour. Res., 46, W06520, http://dx.doi.org/10.1029/2009WR008203 2010.

Hall, D., Riggs, G., Salomonson, V., DiGirolamo, N., and Bayr, K.: MODIS snow-cover products, Remote Sens. Environ., 83, 181194, 2002.

Hansen, M. C., DeFries, R. S., Townshend, J. R. G., and Sohlberg, R.: Global land cover classification at $1 \mathrm{~km}$ spatial resolution using a classification tree approach, Int. J. Remote Sens., 21, 13311364, 2000.

Henderson-Sellers, A., Yang, Z. L., and Dickinson, R. E.: The Project for Intercomparison of Land-surface Parameterization Schemes, B. Am. Meteorol. Soc., 74, 1335-1349, 1993.

Henderson-Sellers, A., Pitman, A. J., Love, P. K., Irannejad, P., and Chen, T. H.: The project for intercomparison of land surface parameterization schemes (PILPS): Phases 2 and 3, B. Am. Meteorol. Soc., 76, 489-503, 1995.

Henricksen, B. L. and Durkin, J. W.: Growing period and drought early warning in Africa using satellite data, Int. J. Remote Sens., 7, 1583-1608, 1986.

Houser, P. R., Shuttleworth, W. J., Famiglietti, J. S., Gupta, H. V., Syed, K. H., and Goodrich, D. C.: Integration of soil moisture remote sensing and hydrologic modeling using data assimilation, Water Resour. Res., 34, 3405-3420, 1998.

Huete, A., Didan, K., Miura, T., Rodriguez, E. P., Gao, X., and Ferreira, L. G.: Overview of the radiometric and biophysical performance of the MODIS vegetation indices, Remote Sens. Environ., 83, 195-213, 2002.

Huffman, G. J., Adler, R. F., Bolvin, D. T., Gu, G. J., Nelkin, E. J., Bowman, K. P., Hong, Y., Stocker, E. F., and Wolff, D. B.: The TRMM multisatellite precipitation analysis (TMPA): Quasi- 
global, multiyear, combined-sensor precipitation estimates at fine scales, J. Hydrometeorol., 8, 38-55, 2007.

Immerzeel, W. and Droogers, P.: Calibration of a distributed hydrological model based on satellite evapotranspiration, J. Hydrol., 349, 411-424, 2008.

Jones, D., Wang, W., and Fawcett, R.: High-quality spatial climate data-sets for Australia, Aust. Meteorol. Oceanogr. J., 58, 233248, 2009.

Joyce, R., Janowiak, J., Arkin, P., and Xie, P.: CMORPH: A method that produces global precipitation estimates from passive microwave and infrared data at high spatial and temporal resolution, J. Hydrometeorol., 5, 487-503, 2004.

Kalma, J., McVicar, T., and McCabe, M.: Estimating Land Surface Evaporation: A Review of Methods Using Remotely Sensed Surface Temperature Data, Surv. Geophys., 29, 421-469, 2008.

Kalnay, E.: Atmospheric Modeling, Data Assimilation, and Predictability, Cambridge University Press Cambridge, UK, 2003.

Kampf, S. and Burges, S.: A framework for classifying and comparing distributed hillslope and catchment hydrologic models, Water Resour. Res., 43, W05423, doi:10.1029/2006WR005370, 2007.

Kellndorfer, J., Walker, W., Pierce, L., Dobson, C., Fites, J. A., Hunsaker, C., Vona, J., and Clutter, M.: Vegetation height estimation from shuttle radar topography mission and national elevation datasets, Remote Sens. Environ., 93, 339-358, 2004.

King, E. A., Paget, M. J., Briggs, P. R., Raupach, M. R., and Trudinger, C. M.: Operational Delivery of Hydrometeorological Monitoring and Modelling over the Australian Continent, IEEE Journal Of Selected Topics In Earth Observations and Remote Sensing, 2, 241-249, 2010.

Kite, G. W. and Droogers, P.: Comparing evapotranspiration estimates from satellites, hydrological models and field data, J. Hydrol., 229, 3-18, 2000.

Knyazikhin, Y., Glassy, J., Privette, J., Tian, Y., Lotsch, A., Zhang, Y., Wang, Y., Morisette, J., Votava, P., and Myneni, R.: MODIS leaf area index (LAI) and fraction of photosynthetically active radiation absorbed by vegetation (FPAR) product (MOD15) algorithm theoretical basis document, Theoretical Basis Document, NASA Goddard Space Flight Center, Greenbelt, MD, 20771, 1999.

Kumar, S., Peters-Lidard, C., Yudong, T., Reichle, R., Geiger, J., Alonge, C., Eylander, J., and Houser, P.: An Integrated Hydrologic Modeling and Data Assimilation Framework, Computer, 41, 52-59, 2008.

Laguardia, G. and Niemeyer, S.: On the comparison between the LISFLOOD modelled and the ERS/SCAT derived soil moisture estimates, Hydrol. Earth Syst. Sci., 12, 1339-1351, doi:10.5194/hess-12-1339-2008, 2008.

Liang, X., Lettenmaier, D. P., Wood, E. F., and Burges, S. J.: A Simple hydrologically Based Model of Land Surface Water and Energy Fluxes for GSMs J. Geophys. Res., 99(D7), 14415-14428, 1994.

Liu, Y.: Trends and patterns in 30 years of soil and vegetation moisture observations over Australia, Water On The Radar: use of microwaves in water resources management, 2 July 2008, Canberra, 2008.

Liu, Y., De Jeu, R. A. M., Van Dijk, A. I. J. M., and Owe, M.: TRMM-TMI satellite observed soil moisture and vegetation density (1998-2005) show strong connection with El Niño in eastern Australia, Geophys. Res. Lett., 34, L15401, 5 pp.,
doi:10.1029/2007/GL030311, 2007.

Liu, Y. Y., Evans, J. P., McCabe, M. F., de Jeu, R. A. M., van Dijk, A. I. J. M., and Su, H.: Influence of cracking clays on satellite estimated and model simulated soil moisture, Hydrol. Earth Syst. Sci., 14, 979-990, doi:10.5194/hess-14-979-2010, 2010.

Lo, M. H., Famiglietti, J. S., Yeh, P. J. F., and Syed, T. H.: Improving parameter estimation and water table depth simulation in a land surface model using GRACE water storage and estimated base flow data, Water Resour. Res., 46, W05517, doi:10.1029/2009WR007855, 2010.

Lohmann, D., Mitchell, K., Houser, P., Wood, E., Schaake, J., Robock, A., Cosgrove, B., Sheffield, J., Duan, Q., and Luo, L.: Streamflow and water balance intercomparisons of four land surface models in the North American Land Data Assimilation System project, J. Geophys. Res., 109, 22 pp., 2004.

Mattikalli, N. M., Engman, E. T., Ahuja, L. R., and Jackson, T. J.: Microwave remote sensing of soil moisture for estimation of profile soil property, Int. J. Remote Sens., 19, 1751-1767, 1998.

Meesters, A., De Jeu, R. A. M., and Owe, M.: Analytical derivation of the vegetation optical depth from the microwave polarization difference index, IEEE Geosci. Remote Sens. Lett., 2, 121, 2005.

Mitchell, K., Lohmann, D., Houser, P., Wood, E., Schaake, J., Robock, A., Cosgrove, B., Sheffield, J., Duan, Q., and Luo, L.: The multi-institution North American Land Data Assimilation System (NLDAS): Utilizing multiple GCIP products and partners in a continental distributed hydrological modeling system, J. Geophys. Res., 109, D07S90, doi:10.1029/2003JD003823, 2004.

Molden, D.: Accounting for water use and productivity, SWIM paper, 1, 4-10, 1997.

Monteith, J. L.: Evaporation and environment, Symposia of the Society for Experimental Biology, 19, 205-224, 1965.

Mucher, C. A., Steinnocher, K. T., Kressler, F. P., and Heunks, C.: Land cover characterization and change detection for environmental monitoring of pan-Europe, Int. J. Remote Sens., 21, 1159-1181, 2000.

Myneni, R., Hoffman, S., Knyazikhin, Y., Privette, J., Glassy, J., Tian, Y., Wang, Y., Song, X., Zhang, Y., and Smith, G.: Global products of vegetation leaf area and fraction absorbed PAR from year one of MODIS data, Remote Sens. Environ., 83, 214-231, 2002.

Nijssen, B., O’Donnell, G., Hamlet, A., and Lettenmaier, D.: Hydrologic Sensitivity of Global Rivers to Climate Change, Climatic Change, 50, 143-175, 2001.

Oki, T., Nishimura, T., and Dirmeyer, P.: Assessment of Annual Runoff from Land Surface Models Using Total Runoff Integrating Pathways (TRIP), J. Meteorol., 77, 235-255, 1999.

Ottlé, C. and Vidal-Madjar, D.: Estimation of land surface temperature with NOAA9 data, Remote Sens. Environ., 40, 27-41, 1992.

Ottlé, C. and Vidal-Madjar, D.: Assimilation of soil moisture inferred from infrared remote sensing in a hydrological model over the HAPEX-MOBILHY region, J. Hydrol., 158, 241-264, 1994.

Pan, M., Wood, E. F., McLaughlin, D., Entekhabi, D., and Luo, L.: A Multiscale Ensemble Filtering System for Hydrologic Data Assimilation: Part I, Implementation and Synthetic Experiment, J. Hydrometeorol., 10, 794-806, doi:10.1175/2009JHM1088.1, 2009.

Parajka, J., Naeimi, V., Blöschl, G., Wagner, W., Merz, R., and Scipal, K.: Assimilating scatterometer soil moisture data into con- 
ceptual hydrologic models at the regional scale, Hydrol. Earth Syst. Sci., 10, 353-368, doi:10.5194/hess-10-353-2006, 2006.

Parajka, J., Naeimi, V., Blöschl, G., and Komma, J.: Matching ERS scatterometer based soil moisture patterns with simulations of a conceptual dual layer hydrologic model over Austria, Hydrol. Earth Syst. Sci., 13, 259-271, doi:10.5194/hess-13-259-2009, 2009.

Pathe, C., Wagner, W., Sabel, D., Bartalis, Z., Doubkova, M., and Naeimi, V.: Using ENVISAT ASAR Global Mode data for surface soil moisture retrieval over Oklahoma, USA, IEEE T. Geosci. Remote, 47, 468-480, 2009.

Pauwels, V. R. N., Hoeben, R., Verhoest, N. E. C., Troch, F. P. D., and Troch, P. A.: Improvement of TOPLATS-based discharge predictions through assimilation of ERS-based remotely sensed soil moisture values, Hydrol. Process., 16, 995-1013, 2002.

Pauwels, V. R. N., Balenzano, A., Satalino, G., Skriver, H., Verhoest, N. E. C., and Mattia, F.: Optimization of Soil Hydraulic Model Parameters Using Synthetic Aperture Radar Data: An Integrated Multidisciplinary Approach, IEEE T. Geosci. Remote., 47, 455-467, 2009.

Poli, P.: Assimilation of satellite observations of the atmosphere, Comptes Rendus Geoscience, 342, 357-369, 2010.

Priestley, C. H. B. and Taylor, R. J.: On the assessment of surface heat flux and evaporation using large-scale parameters, Mon. Weather Rev., 100, 81-92, 1972.

Prigent, C., Tegen, I., Aires, F., Marticorena, B., and Zribi, M.: Estimation of the aerodynamic roughness length in arid and semiarid regions over the globe with the ERS scatterometer, J. Geophys. Res, 110, D09205.1-D09205.12, 2005.

Qin, C., Jia, Y., Su, Z., Zhou, Z., Qiu, Y., and Suhui, S.: Integrating Remote Sensing Information Into A Distributed Hydrological Model for Improving Water Budget Predictions in Large-scale Basins through Data Assimilation, Sensors, 8, 4441-4465, 2008.

Ramamoorthi, A.: Snow-melt run-off studies using remote sensing data, Sadhana, 6, 279-286, 1983.

Ramillien, G., Famiglietti, J. S., and Wahr, J.: Detection of continental hydrology and glaciology signals from GRACE: a review, Surv. Geophys., 29, 361-374, 2008.

Rango, A. and Shalaby, A.: Operational applications of remote sensing in hydrology: success, prospects and problems/Applications opérationnelles de la télédétection en hydrologie: résultats, projets et problèmes, Hydrolog. Sci. J., 43, 947968, 1998.

Raupach, M. R., Briggs, P. R., Haverd, V., King, E. A., Paget, M., and Trudinger, C. M.: Australian Water Availability Project (AWAP) CSIRO Marine and Atmospheric Research Component: Final Report for Phase 3, CSIRO, Canberra, Australia, 2008.

Renzullo, L. J., Barrett, D. J., Marks, A. S., Hill, M. J., Guerschman, J. P., Mu, Q., and Running, S. W.: Multisensor model-data fusion for estimation of hydrologic and energy flux parameters, Remote Sens. Environ., 112, 306-1319, doi:10.1016/j.rse.2007.06.022, 2008.

Rodell, M., Houser, P., Jambor, U., Gottschalck, J., Mitchell, K., Meng, C., Arsenault, K., Cosgrove, B., Radakovich, J., and Bosilovich, M.: The global land data assimilation system, B. Am. Meteorol. Soc., 85, 381-394, 2004.

Schaaf, C. B., Gao, F., Strahler, A. H., Lucht, W., Li, X. W., Tsang, T., Strugnell, N. C., Zhang, X. Y., Jin, Y. F., Muller, J. P., Lewis,
P., Barnsley, M., Hobson, P., Disney, M., Roberts, G., Dunderdale, M., Doll, C., d'Entremont, R. P., Hu, B., Liang, S., Privette, J. L., Roy, D.: First operational BRDF, albedo nadir reflectance products from MODIS, Remote Sens. Environ., 83, 135-148, 2002.

Schmugge, T. J., Kustas, W. P., Ritchie, J. C., Jackson, T. J., and Rango, A.: Remote sensing in hydrology, Adv. Water Res., 25, 1367-1385, 2002.

Schultz, G. and Engman, E.: Remote sensing in hydrology and water management, Springer, Berlin, 2000.

Schuurmans, J. M., Troch, P. A., Veldhuizen, A. A., Bastiaanssen, W. G. M., and Bierkens, M. F. P.: Assimilation of remotely sensed latent heat flux in a distributed hydrological model, Adv. Water Resour., 26, 151-159, 2003.

Simmons, A. and Hollingsworth, A.: Some aspects of the improvement in skill of numerical weather prediction, Q. J. Roy. Meteor. Soc., 128, 647-677, 2002.

Tapley, B. D., Bettadpur, S., Ries, J. C., Thompson, P. F., and Watkins, M. M.: GRACE Measurements of Mass Variability in the Earth System, Science, 305, 503-505, doi:10.1126/science.1099192, 2004.

Thielen, J., Bartholmes, J., Ramos, M.-H., and de Roo, A.: The European Flood Alert System - Part 1: Concept and development, Hydrol. Earth Syst. Sci., 13, 125-140, doi:10.5194/hess-13-1252009, 2009.

Tracton, M. S, and McPherson, R. D.: On the impact of radiometric sounding data upon operational numerical weather prediction at NMC, B. Am. Meteorol. Soc., 58, 1201-1209, 1977.

Troch, P. A., Paniconi, C., and McLaughlin, D.: Catchment-scale hydrological modeling and data assimilation, Adv. Water Resour., 26, 131-135, 2003.

Van der Knijff, J. M., Younis, J., and De Roo, A. P. J.: LISFLOOD: a GIS-based distributed model for river basin scale water balance and flood simulation, Int. J. Geogr. Inf. Sci., 24, 189-212, 2010.

Van Dijk, A. I. J. M.: Climate and terrain factors explaining streamflow response and recession in Australian catchments, Hydrol. Earth Syst. Sci., 14, 159-169, doi:10.5194/hess-14-159-2010, 2010.

Van Dijk, A. I. J. M. and Renzullo, L. J.: The Australian Water Resources Assessment system: blending water cycle observations and models at local and continental scale, GEWEX-iLeaps, Melbourne, 2009a.

Van Dijk, A. I. J. M. and Renzullo, L. J.: The Australian Water Resources Assessment system: blending satellite data into a water resources observation system for Australia, Earth Observation and Water Cycle Science, Frascati, Italy, 18-20 November 2009, 2009 b.

Van Dijk, A. I. J. M. and Renzullo, L. J.: Evaluation of alternative model-data fusion approaches in retrospective water balance estimation across Australia, 18th World IMACS Congress and MODSIM09 International Congress on Modelling and Simulation, Cairns, Australia, 2009c.

Van Dijk, A. I. J. M.: AWRA Technical Report 3, Landscape Model (version 0.5) Technical Description, WIRADA/CSIRO Water for a Healthy Country Flagship, http://www.clw.csiro.au/publications/waterforahealthycountry/ 2010/wfhc-aus-water-resources-assessment-system.pdf, (last access: 4 January 2010), Canberra, 2010a.

Van Dijk, A. I. J. M.: Selection of an appropriately simple 
storm runoff model, Hydrol. Earth Syst. Sci., 14, 447-458, doi:10.5194/hess-14-447-2010, 2010.

Van Dijk, A. I. J. M. and Warren, G.: AWRA Technical Report 4, Evaluation Against Observations, WIRADA/CSIRO Water for a Healthy Country Flagship, http://www.clw.csiro.au/publications/waterforahealthycountry/ 2010/wfhc-aus-water-resources-assessment-system.pdf, (last access: 4 January 2010), Canberra, 2010.

Van Dijk, A. I. J. M., Guerschman, J. P., and Warren, G. A.: Satellite mapping of areas evaporating river and groundwater flows, Geophys. Res. Abstr., 7847, 2010.

Vazifedoust, M., van Dam, J. C., Bastiaanssen, W. G. M., and Feddes, R. A.: Assimilation of satellite data into agrohydrological models to improve crop yield forecasts, Int. J. Remote Sens., 30, 2523-2545, 2009.

Vischel, T., Pegram, G. G. S., Sinclair, S., Wagner, W., and Bartsch, A.: Comparison of soil moisture fields estimated by catchment modelling and remote sensing: a case study in South Africa, Hydrol. Earth Syst. Sci., 12, 751-767, doi:10.5194/hess-12-7512008, 2008.

Vörösmarty, C., Green, P., Salisbury, J., and Lammers, R.: Global water resources: vulnerability from climate change and population growth, Science, 289, 284, 2000.

Wagner, W., Verhoest, N. E. C., Ludwig, R., and Tedesco, M.: Editorial "Remote sensing in hydrological sciences", Hydrol. Earth Syst. Sci., 13, 813-817, doi:10.5194/hess-13-813-2009, 2009.

Weerts, A. H., Berendrecht, W. L., Veldhuizen, A., Goorden, N., Vernimmen, R., Lourens, A., Prinsen, G., Mulder, M., Kroon, T., and Stam, J.: Drought forecasting system of the Netherlands, Geophys. Res. Abstr., EGU2009-1765-2002, 2009.

Werner, M. and Whitfield, D.: On model integration in operational flood forecasting, Hydrol. Process., 21, 1519-1521, 2007.
Weymouth, G. T. and Le Marshall, J. F.: Estimate of daily surface solar exposure using GMS-5 stretched-VISSR observations, The system and basic results, Aust. Meteorol. Mag., 50, 263-278, 2001.

Winsemius, H. C., Savenije, H. H. G., and Bastiaanssen, W. G. M.: Constraining model parameters on remotely sensed evaporation: justification for distribution in ungauged basins?, Hydrol. Earth Syst. Sci., 12, 1403-1413, doi:10.5194/hess-12-14032008, 2008.

Wood, E., Lettenmaier, D., and Zartarian, V.: A land-surface hydrology parameterization with subgrid variability for general circulation models, J. Geophys. Res., 97, 2717-2728, 1992.

Wood, E. F., Lettenmaier, D. P., Liang, X., Lohmann, D., Boone, A., Chang, S., Chen, F., Dai, Y., Dickinson, R. E., Duan, Q., Ek, M., Gusev, Y. M., Habets, F., Irannejad, P., Koster, R., Mitchel, K. E., Nasonova, O. N., Noilhan, J., Schaake, J., Schlosser, A., Shao, Y., Shmakin, A. B., Verseghy, D., Warrach, K., Wetzel, P., Xue, Y., Yang, Z.-L., and Zeng, Q.-C.: The Project for Intercomparison of Land-surface Parameterization Schemes (PILPS) Phase 2(c) Red-Arkansas River basin experiment: 1. Experiment description and summary intercomparisons, Global Planet. Change, 19, 115-135, 1998.

Xie, P. and Arkin, P.: Global precipitation: A 17-year monthly analysis based on gauge observations, satellite estimates, and numerical model outputs, B. Am. Meteorol. Soc., 78, 2539-2558, 1997.

Zaitchik, B. F., Rodell, M., and Reichle, R. H.: Assimilation of GRACE Terrestrial Water Storage Data into a Land Surface Model: Results for the Mississippi River Basin, J. Hydrometeorol., 9, 535-548, doi:10.1175/2007JHM951.1, 2008.

Zhang, L. and Dawes, W. R.: WAVES - An integrated energy and water balance model, CSIRO, Canberra, 177, 1998.

Zhang, L., Dawes, W. R., and Walker, G. R.: Response of mean annual evapotranspiration to vegetation changes at catchment scale, Water Resour. Res., 37, 701-708, 2001. 